\title{
Hepatitis: Prevalence, Risk Factors and Associated Co-morbidities in Local Population of Karachi, Pakistan
}

\author{
Ali $\mathrm{H}^{1 *}$, Zafar $\mathrm{F}^{1}$, Korai $\mathrm{O}^{4}$, Siddiqui $\mathbf{S}^{1}$, Naveed $\mathrm{S}^{3}$, Baloch $\mathbf{S A}^{1}$, Asad $\mathbf{S}^{2}$ and Fatima $\mathbf{R}^{1}$ \\ ${ }^{1}$ Faculty of Pharmacy, Ziauddin University, Karachi, Pakistan \\ ${ }^{2}$ Department of Pharmacy, Ziauddin Hospital, Karachi, Pakistan \\ ${ }^{3}$ Faculty of Pharmacy, Jinnah University for Women, Karachi, Pakistan \\ ${ }^{4}$ Faculty of Pharmacy, Federal Urdu University for Arts, Science and Technology, Karachi, Pakistan
}

\begin{abstract}
Hepatitis is inflammatory condition of liver due to a viral infection which may results in acute and chronic form. Types A, B, and C are most prevalent hepatitis viruses. Frequent mode of transmission of these infections include oral, fecal and parenteral route. Hepatitis $B, C$ and $D$ are mainly transmitted through infected blood. Pakistan is endemic area for viral hepatitis $B$ and $C$ and their prevalence was estimated with $7.4 \%$ infection rate in 2009 . This population focused study with objective of monitoring of health status of local residents was carried out from February to July 2014 in Karachi, Pakistan. Data was collected $(\mathrm{N}=200)$ from patients and physicians using structured Questionnaire and by also reviewing medical records of subjects from various hospitals and clinics and interpreted to evaluate the risk factors, prevalence and associated comorbidities of hepatitis in local population. Rate of infection with Hepatitis C was found high (58\%), followed by Hepatitis B $(24 \%)$. Few cases of Hepatitis D coexisted with hepatitis B were also observed. Frequency of Hepatitis A was observed $10 \%$. Different modes of viral transmission were also studied. Results were calculated with SPSS 20.0, using chi square and independent $t$-tests. It was also concluded that Hepatitis B and C infections are vital factors for causing drastic morbidity and mortality. Hence Initiation of awareness programs along with effective preventive measure is important to reduce the high prevalence of hepatitis in society.
\end{abstract}

Keywords: Prevalence; Hepatitis; Risk factors; Awareness; Mode of transmission; Karachi

\section{Introduction}

Health and literacy rate of Pakistan is below standard mark. Pakistan as a developing country is ranked $134^{\text {th }}$ out of 174 countries in a report published by Human development index of the United Nations [1]. Rate of infection with hepatitis B and C is high in Pakistan as 12 million individuals are suspected to have this disease [2]. Beside these findings, In Pakistan foremost reason of acute viral hepatitis (AVH) is hepatitis E virus (HEV) mostly found in adult's population having low socioeconomic values and fecal contamination of water is the main source for spread of this disease [3]. General features of hepatitis virus A, B, C, D and E are presented in Table 1. Factors associated with high prevalence of infections include poor regulation of health standards for transmission of blood, inappropriate use of recycled and low quality needles and syringes, non-sterilized surgical tools and dental instruments, repeated exposure of infected syringes in drug users, tattooing, nose and ear piercing and shaving using same needle or blade, haemodialysis, sexual intercourse, needle-stick injuries and peri-natal infections [4,5]. Mostly hepatitis infections are acute but $\mathrm{B}, \mathrm{C}$ and $\mathrm{D}$ may also lead to chronic infections, associated co- morbidities, disability and death [5-8]. Substantial proportion of liver diseases is associated with hepatitis $\mathrm{B}$ and $\mathrm{C}$ virus infections. According to WHO 2004 report yearly mortalities were found 308,000 and 785,000 respectively by liver cancer and cirrhosis caused by HCV while WHO also rated Pakistan as $2^{\text {nd }}$ amongst world countries having drastically high rates of chronic infectivity. About 8.6 Million Pakistanis are affected with hepatitis C [9]. Co-infections with hepatitis are not infrequent, which also present a challenge for treatment of these conditions [10]. Estimated complications of these chronic infections are expected to rise in next few decades dramatically and hence eventually burdenize the health setup of a disease with greater annual health care expenditure $[11,12]$.

Incredible efforts are obligatory to promote awareness in public and proper education programs need to be initiated regarding risk and hazards associated with transmission of viruses $[13,14]$. In present work, we studied the prevalence, mode of transmissions, risk factors, associated co-morbidities and treatment available for hepatitis in local population of Karachi, Pakistan. The main purpose of this study was to assess and monitor the health status of local population with the objective to figure out the related facts for this disease.

\section{Material and Methods}

\section{Study design}

This observational descriptive study was conducted between February to July 2014 and data was collected from different areas of Karachi, Pakistan (Clinics and Hospitals). Individuals having hepatitis infections were incorporated in this study. A well-designed questionnaire was developed which consisted of 20 close-ended plus 5 open ended questions. The format of questionnaire was designed to acquire important information about the respondents' disease type, severity and intensity, associated comorbidities, modes of transmission, and treatment protocols. Patient's demographic data was also tabulated for disease prevalence with respect to age and sex. During this study patient medical records were studied, and their lab values for liver function test (LFT), hemoglobin and Creatinine clearance were noted down. Furthermore patients and physicians were also interviewed for

*Corresponding author: Ali H, Faculty of Pharmacy, Ziauddin University, Karachi, Pakistan, Tel: 0332-3011380; E-mail: humaali80@live.com

Received November 24, 2014; Accepted December 29, 2014; Published December 31, 2014

Citation: Ali H, Zafar F, Korai O, Siddiqui S, Naveed S, et al. (2015) Hepatitis: Prevalence, Risk Factors and Associated Co-morbidities in Local Population of Karachi, Pakistan. J Bioequiv Availab 7: 051-055. doi:10.4172/jbb.1000213

Copyright: @ 2015 Ali $\mathrm{H}$, et al. This is an open-access article distributed under the terms of the Creative Commons Attribution License, which permits unrestricted use, distribution, and reproduction in any medium, provided the original author and source are credited. 
Citation: Ali H, Zafar F, Korai O, Siddiqui S, Naveed S, et al. (2015) Hepatitis: Prevalence, Risk Factors and Associated Co-morbidities in Local Population of Karachi, Pakistan. J Bioequiv Availab 7: 051-055. doi:10.4172/jbb.1000213

\begin{tabular}{|c|c|c|c|c|c|c|}
\hline Type & Transmission & Classification & Genome & Antigens & Incubation period & Chronicity \\
\hline HAV & Enteric & Picornavirus & +ssRNA & - & $15-45$ days & No \\
\hline HBV & Parenteral & Hepadnavirus & $+d s D N A$ & $\mathrm{HBsAg}, \mathrm{HBeAg}$ & $45-160$ days & Yes (common) \\
\hline HCV & Parenteral & Hepacivirus & +ssRNA & Core antigen & $15-150$ days & Yes (common) \\
\hline HDV & Parenteral & Deltavirus & -ssRNA & Delta antigen & $30-60$ days & Yes - with hepatitis B \\
\hline HEV & Enteric & Hepevirus & +ssRNA & - & $15-60$ days & No \\
\hline
\end{tabular}

Note: HAV (hepatitis A virus), HBV (hepatitis B virus), HCV (hepatitis C virus), HDV (hepatitis D virus), HAV (hepatitis E virus)

Table 1: General Features of Hepatitis Viruses.

\begin{tabular}{|c|c|c|c|c|c|c|}
\hline \multirow{2}{*}{ Age Group } & \multicolumn{2}{|c|}{ Total $\quad \mathrm{N}=\mathbf{2 0 0}$} & \multicolumn{2}{|c|}{ Female $\mathrm{N}=107$} & \multicolumn{2}{|c|}{ Male $\mathrm{N}=93$} \\
\hline & No. & $\%$ & No. & $\%$ & No. & $\%$ \\
\hline $12-20$ & 25 & 12.5 & 15 & 14.1 & 10 & 10.7 \\
\hline $21-30$ & 42 & 21.0 & 19 & 17.7 & 23 & 24.7 \\
\hline $31-50$ & 57 & 28.5 & 30 & 28.0 & 27 & 29.0 \\
\hline Above 50 & 76 & 38.0 & 43 & 40.1 & 33 & 35.4 \\
\hline
\end{tabular}

Table 2: Age and Sex Distribution of Study Samples of Hepatitis.



Figure 1: Severity of Disease.

collection of relevant information including their knowledge regarding disease transmission. 100 cases from tertiary care hospitals were also included in this study and investigated for severity and frequency of viral hepatitis A, B, C, D and E. Results were analyzed by chi square $\chi^{2}$ and independent sample $t$ tests using SPSS 20.0

\section{Result and Discussion}

Hepatitis is becoming a serious health issue of developing countries, including Pakistan. Great numbers of research studies are performed with various cohorts of population including drug users, blood donors, and professional engaged to healthcare setup to signify the dominance of hepatitis in society [15-17]. However, mass awareness is still needed about the spread, symptoms, severity, treatment and prevention of this disease with associated morbidity and mortalities [18].

Present study was aimed to determine the prevalence of hepatitis in local population of Karachi, Pakistan and was comprised of convenience sample $\mathrm{N}=200$. Patients were divided in four age groups including 12$20 \mathrm{yrs}$ (12.5\%), 21-30 yrs (21\%), 31- $50 \mathrm{yrs}$ (28.5\%) and above $50 \mathrm{yrs}$ $(38 \%)$. Effect of age and sex in relevance to hepatitis was assessed in different studies. Ghias and Khalid also indicated the impact of age and calculated that one year increment in patient age can increase the risk of disease with factor of 1.034 times, while increment will double with 20 years increment in age calculated as $\exp ^{\left(10^{*} 0.034\right)}=2.0$.

In current study high prevalence of disease was found in patients above 50 yrs i.e. $38 \%$ (Table 2). For collection of the data structured questionnaire was developed with open and close ended questions and then information was collected from patients and physicians. Beside that 100 patients were also included in this study that were admitted in different wards of tertiary care hospital and were also grouped in further six categories according to the severity of disease and admissions in different wards (Figure 1). Record of patients admitted in various wards of tertiary care hospitals having Hepatitis A, B, C, D or $\mathrm{E}$ is also presented in Figure 2.

In the present study the frequency of hepatitis A was found 10 $\%$. Personal and public hygiene critically influence the epidemiology of hepatitis A virus. In Pakistan hepatitis A is present pandemic to epidemics especially in hot and rainy periods $[19,20]$. Frequency of hepatitis B in this study was estimated to be $24 \%$, hepatitis C $58 \%$, hepatitis E $12 \%$ and low prevalence of Hepatitis D i.e. 4\% (Figure 3). Adult groups are more prone to be effected by HEV. Different authors also reported small epidemics of hepatitis E in Pakistan [21,22]. The decrease in frequency of hepatitis B in contrast to Hepatitis $C$ may be related to effective execution of the vaccination plan. Disease prevalence of hepatitis $\mathrm{C}$ in Pakistan was also reported in different studies between 4.6 to $23.8 \%$ [23,24]. While high Prevalence in Africa and Asia is also reported by number of authors [25-27]. Comprehensive strategies need to develop and implement to reduce the disease transmission with vaccination campaigns. Communities counseling and education with respect to spread of disease is also important to commence. Routine childhood vaccination can also decline the age related burden of hepatitis.

During the study patient and physicians were asked for the main causes and spread of disease. Respondents rated drug users with common syringes (41\%), transfused blood (24\%), infected equipment (12\%), followed by tattooing and ear piercing (6\%), while $17 \%$ was found with unknown causes (Table 3). Around 350 million HBV positive cases were estimated in 2004 worldwide and over 10\% in Asia. 
Citation: Ali H, Zafar F, Korai O, Siddiqui S, Naveed S, et al. (2015) Hepatitis: Prevalence, Risk Factors and Associated Co-morbidities in Local Population of Karachi, Pakistan. J Bioequiv Availab 7: 051-055. doi:10.4172/jbb.1000213

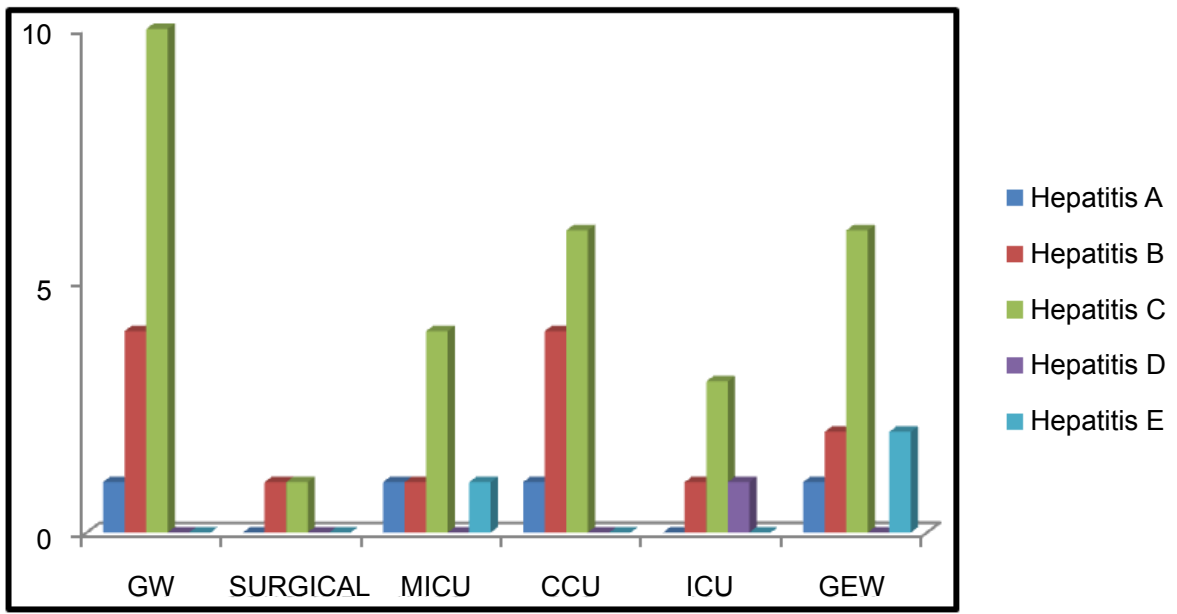

Note: GW (general ward), MICU (medical intensive care unit), CCU (critical care unit), ICU (intensive care unit), GEW (gastroenterology ward)

Figure 2: Record of patients admitted in various wards of tertiary care hospitals having Hepatitis A, B, C, D or E (severity of symptoms).

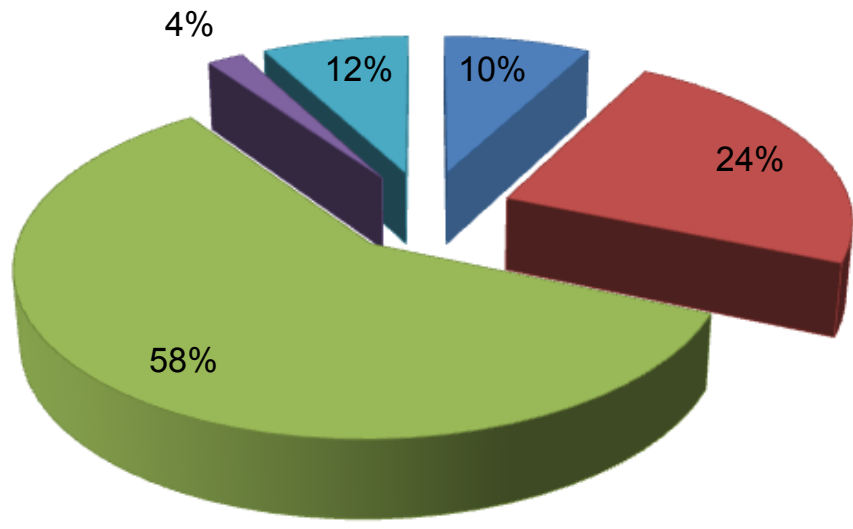

Hepatitis A

Hepatitis B

$\square$ Hepatitis C

Hepatitis D

Hepatitis E

Figure 3: Prevalence of Hepatitis

In various studies different mode of transmissions mainly drug abuse by injections, unprotected sex and transmission during childbirth were supposed to be the primary factors for spread of disease [28-30]. In another study rate of spread of hepatitis $C$ was found 3-4 million per year [31]. Important labs finding including bilirubin aspartate aminotransferase (AST or SGOT), alanine amino-transferase (ALT or SGPT), hemoglobin and Creatinine values of respondents having viral hepatitis were presented in Table 4 . These were extracted by reviewing the patient's medical records. These lab values were used in determining the disease intensity and rationale prescribing of medications. Normal range of total, direct and indirect bilirubin in adult's is found in order of $0.0-1.4 \mathrm{mg} / \mathrm{dL}$ or $1.7-20.5 \mathrm{mcmol} / \mathrm{L}, 0.0-0.3 \mathrm{mg} / \mathrm{dL}$ or $1.7-5.1 \mathrm{mcmol} / \mathrm{L}$ and $0.2-1.2 \mathrm{mg} / \mathrm{dL}$ or $3.4-20.5 \mathrm{mcmol} / \mathrm{L}$. higher levels of these factors indicates the progression or development of hepatitis, cirrhosis and other liver diseases $[32,33]$. The customary values of aspartate aminotransferase (AST or SGOT) and alanine amino-transferase (ALT or SGPT) are ranged between 5 to 40 and 7-56 units per liter of serum. In case of liver injury due to hepatitis or other conditions levels of these enzymes change in blood and indicate the liver damage. Like in case of hepatitis A, very high levels of AST and ALT even in 1000U/L may found while in other cases including infection with HCV and other chronic liver diseases slight elevation of these enzymes can occur.
Hence, these enzymes are not used as sole indicators to forecast the liver damage [34-36].

The most prevalent comorbidities of viral hepatitis were also

\begin{tabular}{|c|c|}
\hline Modes of transmission & Percentage of prevalence (\%) \\
\hline Syringes & 41 \\
\hline Transfused Blood & 24 \\
\hline Tattooing/ ear and Nose piercing & 6 \\
\hline Infected Equipment & 12 \\
\hline Unknown Reasons & 17 \\
\hline
\end{tabular}

Table 3: Respondents Knowledge about Modes of Transmission.

\begin{tabular}{|c|c|c|c|c|c|}
\hline \multirow[b]{2}{*}{ S.No. } & \multicolumn{3}{|c|}{ Liver function test } & \multirow[b]{2}{*}{$\mathrm{Hb}$ (mg/dL) } & \multirow[b]{2}{*}{$\begin{array}{c}\text { Creatinine } \\
\text { (mg/dL) }\end{array}$} \\
\hline & $\begin{array}{l}\text { BILIRUBIN } \\
\text { (mg/dL) }\end{array}$ & AST(U/L) & $A L T(U / L)$ & & \\
\hline & $0.79-48$ & & & & \\
\hline Hepatitis B & $0.54-85.5$ & $28-1332$ & $2-1$ & $9.26-16.2$ & $0.41-1.58$ \\
\hline Hepatitis C & $0.43-64.9$ & $20-4095$ & $28-2262$ & $10.1-16.6$ & $0.64-4.54$ \\
\hline Hepatitis D & $0.50-3.2$ & $25-86$ & $57-1$ & $9.12-11.8$ & $0.72-1.25$ \\
\hline Hepatitis E & $1.42-21.5$ & $47-1400$ & $310-2262$ & $9.02-15.1$ & $0.98-1.52$ \\
\hline
\end{tabular}

Table 4: Important Labs Finding of Respondents Having Viral Hepatitis $(\mathrm{N}=200)$. 
Citation: Ali H, Zafar F, Korai O, Siddiqui S, Naveed S, et al. (2015) Hepatitis: Prevalence, Risk Factors and Associated Co-morbidities in Local Population of Karachi, Pakistan. J Bioequiv Availab 7: 051-055. doi:10.4172/jbb.1000213

\begin{tabular}{|c|c|c|c|c|c|c|c|c|c|c|c|c|c|c|}
\hline \multirow[t]{2}{*}{ Age Groups } & \multicolumn{2}{|c|}{ Cirhosis } & \multicolumn{2}{|c|}{$\begin{array}{l}\text { Hepato-cellular } \\
\text { carcinoma }\end{array}$} & \multicolumn{2}{|c|}{$\begin{array}{c}\text { Co infections } \\
\text { (Respiratory \& GIT) }\end{array}$} & \multicolumn{2}{|c|}{ Other viral infections } & \multicolumn{2}{|c|}{ Encephalitis } & \multicolumn{2}{|c|}{$\begin{array}{l}\text { Genitourinary } \\
\text { infections }\end{array}$} & \multicolumn{2}{|c|}{$\begin{array}{l}\text { Neurological } \\
\text { disorders }\end{array}$} \\
\hline & Yes & No & Yes & No & Yes & No & Yes & No & Yes & No & Yes & No & Yes & No \\
\hline $12-20 y r s$ & 4 & 21 & 0 & 25 & 13 & 12 & 12 & 13 & 10 & 15 & 6 & 19 & 7 & 18 \\
\hline $21-30 y r s$ & 16 & 26 & 8 & 34 & 21 & 21 & 4 & 38 & 7 & 35 & 7 & 35 & 12 & 30 \\
\hline $31-50 y r s$ & 25 & 32 & 20 & 37 & 21 & 36 & 21 & 36 & 8 & 49 & 8 & 49 & 37 & 20 \\
\hline above $50 y r s$ & 38 & 38 & 28 & 48 & 18 & 58 & 16 & 60 & 13 & 63 & 4 & 72 & 28 & 48 \\
\hline Total & 83 & 117 & 56 & 144 & 73 & 127 & 53 & 147 & 38 & 162 & 25 & 175 & 84 & 116 \\
\hline
\end{tabular}

Table 5: Prevalence of Comorbidities Associated with Viral Hepatitis.

\begin{tabular}{|c|c|c|c|c|c|}
\hline Comorbidities & Value & Df & Asymp. Sig. (2-sided) & Exact Sig. (2-sided) & Exact Sig. (1-sided) \\
\hline Cirrhosis & $9.289^{a}$ & 3 & 0.026 & 0.025 & 0.003 \\
\hline Hepato-cellular carcinoma & $15.760^{\mathrm{a}}$ & 3 & 0.001 & 0.001 & 0.000 \\
\hline Co- infections (Respiratory \& GIT) & $11.282^{\mathrm{a}}$ & 3 & 0.010 & 0.010 & 0.001 \\
\hline Other viral infections & $16.435^{\mathrm{a}}$ & 3 & 0.001 & 0.001 & 0.133 \\
\hline Encephalitis & $8.403^{a}$ & 3 & 0.038 & 0.038 & 0.037 \\
\hline Genitourinary infections & $7.451^{\mathrm{a}}$ & 3 & 0.059 & 0.055 & 0.006 \\
\hline Neurological disorders & $18.234^{a}$ & 3 & 0.000 & 0.000 & 0.130 \\
\hline
\end{tabular}

Table 6: Chi-Square Test for Associated Comorbidities.

\begin{tabular}{|c|c|c|c|c|c|c|c|c|c|c|}
\hline & & \multicolumn{2}{|c|}{$\begin{array}{l}\text { Levene's Test } \\
\text { for Equality of } \\
\text { Variances }\end{array}$} & \multicolumn{7}{|c|}{ t-test for Equality of Means } \\
\hline & & \multirow[t]{2}{*}{$\mathbf{F}$} & \multirow[t]{2}{*}{ Sig. } & \multirow[t]{2}{*}{$\mathbf{t}$} & \multirow[t]{2}{*}{ Df } & \multirow[t]{2}{*}{ Sig. (2-tailed) } & \multirow[t]{2}{*}{ Mean Difference } & \multirow{2}{*}{$\begin{array}{l}\text { Std. Error } \\
\text { Difference }\end{array}$} & \multicolumn{2}{|c|}{$\begin{array}{l}\text { 95\% Confidence Interval of the } \\
\text { Difference }\end{array}$} \\
\hline & & & & & & & & & Lower & Upper \\
\hline \multirow[b]{2}{*}{ Age } & Equal variances assumed & 13.253 & 0.000 & 0.466 & 198 & 0.641 & 0.0691 & 0.1482 & -0.22319 & 0.36147 \\
\hline & $\begin{array}{l}\text { Equal variances not } \\
\text { assumed }\end{array}$ & & & 0.459 & 176.3 & 0.646 & 0.06914 & 0.15047 & -0.22782 & 0.36610 \\
\hline
\end{tabular}

Table 7: Independent Samples Test.

\begin{tabular}{|c|c|c|c|}
\hline Gender & N & Mean & Std. Deviation \\
\hline Female & 93 & 2.9570 & 1.16015 \\
Male & 107 & 2.8879 & 0.12030 \\
\cline { 2 - 5 } & & 0.09038 & 0.93493 \\
\hline
\end{tabular}

Table 8: Group Statistics and Prevalence of Hepatitis.

observed in present study and shown in Table 5. Chi- square test with $0.05 \%$ confidence Interval was used to evaluate the significant values of these comorbidities in patient samples and mulitiple conditions were found significant in different age groups of patients (Table 6) It was also observed that most of the patients suffered with coupled of comorbid symptoms. In previous studies associated co-morbidities of hepatitis $\mathrm{C}$ were also studied and cirrhosis, hepato-cellular carcinoma, and coinfection with HIV were most prevailing with annual deaths rates from 10,000 to $20,000[37,38]$. Prevalence of hepatitis in local population is also estimated with respect to gender by independent $t$-test using SPSS 20.0 (Tables 7 and 8) Available treatments for hepatitis were also recorded from patients profile and summarized in Table 9. It was also observed that different groups of antibiotics were also prescribed including amoxicillin, piperacillin/tazobactum, ceftriaxone, vancocin and meropenum [39-43] according to culture sensitive reports to control secondary bacterial infections, and during the therapies LFT values were closely monitored.

\section{Conclusion}

There is low awareness in community about the risk factors and associated co- morbidities of viral hepatitis. As treatment is costly, so preventive measures should be signified and more awareness for safer blood transfusions, importance of blood screening procedures,

\begin{tabular}{|c|c|}
\hline TYPE OF INFECTION & AVAILABLE TREATMENTS \\
\hline Hepatitis A & $\begin{array}{l}\text { a. Accetaminophen } \\
\text { b. Metaclopramide } \\
\text { c. Immune globulin IM } \\
\text { d. Hepatitis A \& B Vaccines }\end{array}$ \\
\hline Hepatitis B & $\begin{array}{l}\text { a. Tenofovir Disopronil Fumarate } \\
\text { b. Lamivudine } \\
\text { c. Adefovir dipivoxil } \\
\text { d. Entecavir } \\
\text { e. Telbivudine }\end{array}$ \\
\hline Hepatitis C & $\begin{array}{l}\text { a. Protease Inhibitors } \\
\text { - Simeprevir } \\
\text { - Boceprevir } \\
\text { - Telaprevir } \\
\text { b. Interferons } \\
\text { - Interferon alfa- } 2 b \\
\text { - PegInterferon alfa- } 2 b \\
\text { - Pegylated Interferon alfa- } 2 a \\
\text { c. RNA Polymerase Inhibitors } \\
\text { - Sofosbuvir } \\
\text { - Ribavirin } \\
\text { d. Thromboprotien Receptor Agonist } \\
\text { - Eltrombopag }\end{array}$ \\
\hline Hepatitis D & a. Interferon alfa $-2 a$ \\
\hline Hepatitis E & $\begin{array}{l}\text { a. Ribavirin } \\
\text { b. Electrolyte Replacement }\end{array}$ \\
\hline
\end{tabular}

Table 9: Available treatments for hepatitis A, B, C, D and E. 
Citation: Ali H, Zafar F, Korai O, Siddiqui S, Naveed S, et al. (2015) Hepatitis: Prevalence, Risk Factors and Associated Co-morbidities in Local Population of Karachi, Pakistan. J Bioequiv Availab 7: 051-055. doi:10.4172/jbb.1000213

effective techniques of sterilization for equipments, use of disposable blades and syringes must be highlighted in public.

Growing trend of viral hepatitis demands mass awareness and early detection of disease in the country. Thus Preventive measures and effective vaccination program need to be initiated to improve the health and literacy rate. However, a referral bias in this study cannot be excluded. Hence, suggest larger population focused studies to corroborate these findings.

\section{References}

1. World Health Organization. Department of Measurement and Health Information (2004)

2. United Nations Development Program (1996) Human Development Report. Oxford University Press, New York, USA.

3. World Health Organization (2001) Hepatitis E. WHO/CDS/CSR/EDC.

4. Waheed Y, Shafi T, Safi SZ, Qadri I (2009) Hepatitis C virus in Pakistan: a systematic review of prevalence, genotypes and risk factors. World $\mathrm{J}$ Gastroenterol 15: 5647-5653.

5. Agboatwalla M, Isomura S, Miyake K, Yamashita T, Morishita T, et al. (1994) Hepatitis A, B and C seroprevalence in Pakistan. Indian J Pediatr 61: 545-549.

6. Shah U, Habib Z, Kleinman RE (2000) Liver failure attributable to hepatitis A virus infection in a developing country. Pediatrics 105: 436-438.

7. Armstrong GL, Wasley A, Simard EP, McQuillan GM, Kuhnert WL, et al. (2006) The prevalence of hepatitis C virus infection in the United States, 1999 through 2002. Ann Intern Med 144: 705-714.

8. Ghany MG, Strader DB, Thomas DL, Seeff LB; American Association for the Study of Liver Diseases (2009) Diagnosis, management, and treatment of hepatitis C: an update. Hepatology 49: 1335-1374.

9. Hamid S, Umar M, Alam A, Siddiqui A, Qureshi H, et al. (2004) PSG consensus statement on management of hepatitis C virus infection-2003. J Pak Med Assoc 54: 146-150.

10. Liu Z, Hou J (2006) Hepatitis B virus (HBV) and hepatitis C virus (HCV) dual infection. Int J Med Sci 3: 57-62.

11. Davis GL, Albright JE, Cook SF, Rosenberg DM (2003) Projecting future complications of chronic hepatitis $C$ in the United States. Liver Transpl 9: 331 338.

12. Kim WR (2002) The burden of hepatitis C in the United States. Hepatology 36 S30-34.

13. Akhtar S, Rozi S (2009) An autoregressive integrated moving average model for short-term prediction of hepatitis $C$ virus seropositivity among male volunteer blood donors in Karachi, Pakistan. World J Gastroenterol 15: 1607-1612.

14. Luby SP, Qamruddin K, Shah AA, Omair A, Pahsa O, et al. (1997) The relationship between therapeutic injections and high prevalence of hepatitis $C$ infection in Hafizabad, Pakistan. Epidemiol Infect 119: 349-356.

15. Shaikh BT, Hatcher J (2005) Health seeking behaviour and health service utilization in Pakistan: challenging the policy makers. J Public Health (Oxf) 27 49-54.

16. Abbas Z, Jeswani NL, Kakepoto GN, Islam M, Mehdi K, et al. (2008) Prevalence and mode of spread of hepatitis $B$ and $C$ in rural Sindh, Pakistan. Trop Gastroenterol 29: 210-216.

17. Noureen J, Raisa G (2011) A Silent Storm: Hepatitis C in Pakistan. J Pak Med Stud 1: 89-91.

18. Saeedi MI, Mahmood K, Amanullah, Ziauddin M, llyas N, et al. (2004) Frequency and clinical course of hepatitis $\mathrm{E}$ in tertiary care hospitals. J Coll Physicians Surg Pak 14: 527-529.

19. Wasley A, Miller JT, Finelli L (2005) Centers for Disease Control and Prevention (CDC) (2007) Surveillance for acute viral hepatitis--United States. MMWR Surveill Summ 56: 1-24.

20. Kiani IS, Shafi MS, Nasir J, Rehan M. 1999. Prevalence Of Hepatitis - A in healthy adult population of Rawalpindi / Islamabad. Pak J Gastroenterol 131: $1-2$.
21. Tahir Z, Aslam M, Aman S, Tahir ZN (2001) Prevalence of hepatitis E virus (HEV) - IgG antibodies in hospitalized jaundiced patients. Ann King Edward Med Coll 7: 258-259.

22. Shams R, Khero RB, Ahmed T, Hafiz A (2001) Prevalence of hepatitis E virus (HEV) antibody in pregnant women of Karachi. J Ayub Med Coll Abbottabad 13: 31-35.

23. Mirza IA, Mirza SH, Irfan S, Siddiqi R, Tariq WZ, et al. (2006) Seroprevalance of hepatitis $B$ and $C$ in young adults seeking recruitment in armed forces. Pak Armed Forces Med J 56: 192-197.

24. Bosan A, Qureshi H, Bile KM, Ahmad I, Hafiz R (2010) A review of hepatitis viral infections in Pakistan. J Pak Med Assoc 60: 1045-1058.

25. Redd JT, Baumbach J, Kohn W, Nainan O, Khristova M, et al. (2007) Patientto-patient transmission of hepatitis $B$ virus associated with oral surgery. $\mathrm{J}$ Infect Dis 195: 1311-1314.

26. Alter MJ (2003) Epidemiology and prevention of hepatitis B. Semin Liver Dis 23: 39-46.

27. Mujeeb SA (1998) Seroprevalence and pattern of viral hepatitis in Pakistan Infect Dis J Pak 20-21.

28. Center of disease control (CDC) (2008) Chapter 4 - Hepatitis, Viral, Type C Yellow Book, CDC Health Information for International Travel.

29. Sultana N, Bari A, Qazalbash AA (1999) Prevalence of anti-HCV antibodies in patients with liver disease and normal population. Pak J Med Res 38: 106-11.

30. Aziz S, Muzaffar R, Hafiz S, Abbas Z, Zafar MN, et al. (2007) Helicobacter Pylori, Hepatitis Viruses A, C, E, Antibodies and Hbsag - Prevalence and Associated Risk Factors in Pediatric Communities of Karachi. J Coll Physicians Surg Pak 17: 195-198

31. Ruiz JD, Molitor F, Plagenhoef JA (2002) Trends in hepatitis C and HIV infection among inmates entering prisons in California, 1994 versus 1999. AIDS 16: 2236-2238.

32. Gooley TA, Rajvanshi P, Schoch HG, McDonald GB (2005) Serum bilirubin levels and mortality after myeloablative allogeneic hematopoietic cell transplantation. Hepatology 41: 345-352.

33. Thapa BR, Walia A (2007) Liver function tests and their interpretation. Indian Pediatr 74: 663-671.

34. Daniel SP, Marshall MK (1999) Evaluation of the liver: laboratory tests. Schiff's diseases of the liver, 8th (Edn), JB Lippincott publications, USA 205-239.

35. Rosen HR, Keefe EB (2000) Evaluation of abnormal liver enzymes, use of liver tests and the serology of viral hepatitis: Liver disease, diagnosis and management1st (Edn) Churchill livingstone publishers, New York 24-35.

36. Friedman SF, Martin P, Munoz JS (2003) Laboratory evaluation of the patient with liver disease. Hepatology, a textbook of liver disease; Saunders publication, Philedelphia 1: 661-709.

37. Scott JD, McMahon BJ, Bruden D, Sullivan D, Homan C, et al. (2006) High rate of spontaneous negativity for hepatitis $C$ virus RNA after establishment of chronic infection in Alaska Natives. Clin Infect Dis 42: 945-952.

38. Khokhar N, Gill ML, Malik GJ (2004) General seroprevalence of hepatitis C and hepatitis B virus infections in population. J Coll Physicians Surg Pak 14 534-536.

39. Akhtar S, Younus M, Adil S, Jafri SH, Hassan F (2004) Hepatitis C virus infection in asymptomatic male volunteer blood donors in Karachi, Pakistan. J Viral Hepat 11: 527-535.

40. Wake DJ, Cutting WA (1998) Blood transfusion in developing countries: problems, priorities and practicalities. Trop Doct 28: 4-8.

41. Shafi F, Akram S, Kausar S, Banna H (2000) To Study the Risk Factors for Hepatitis C in Cirrhotic Patients. Ann King Edward Med Coll 2: 203-204.

42. Rodger AJ, Roberts S, Lanigan A, Bowden S, Brown T, et al. (2000) Assessment of long-term outcomes of community-acquired hepatitis $C$ infection in a cohort with sera stored from 1971 to 1975 . Hepatology 32: 582-587.

43. Ghias M, Pervaiz MK (2009) Identification of epidemiological risk factors for hepatitis C in Punjab, Pakistan. J Ayub Med Coll Abbottabad 21: 156-161. 